\title{
Alcohol Extract of Wattakaka volubilis (L.F) Stapf Root Inhibits Aldose Reductase to Prevent Diabetes Associated Cataract Formation in Rats
}

\author{
Hajira Banu Haroon, Anita Murali* \\ Department of Pharmacology, Faculty of Pharmacy, M. S. Ramaiah University of Applied Sciences, MSRIT Post, MSR Nagar, \\ Bangalore- 560054, Karnataka, INDIA.
}

\begin{abstract}
Aim: The aim of this study was to investigate the aldose reductase inhibition and anti-cataract property of $W$. volubilis root extract in rats with streptozotocin induced diabetes mellitus. Methods: Diabetes was induced by a single intraperitoneal injection of streptozotocin at the dose of $45 \mathrm{mg} / \mathrm{kg}$. Diabetic animals were treated with glimepiride $(0.5 \mathrm{mg} / \mathrm{kg}$ ) and alcohol extract at 100 and $200 \mathrm{mg} / \mathrm{kg}$ for $38 \mathrm{~d}$. Lens were isolated and certain markers were estimated. Results: Treatment of diabetic animals with alcohol extract of $W$. volubilis root inhibited aldose reductase activity $(p<0.001)$ and sorbitol formation in the lens. Additionally, a reduction in the levels of MDA, GSH, SDH and LDH in extract treated groups was observed. There was an overall decrease in the severity of cataract progression. Conclusion: The result provided evidence that alcohol extract of $W$. volubilis root prevents the development of diabetic cataract in rats.
\end{abstract}

Key words: Wattakaka volubilis, Diabetes mellitus, Cataract, Aldose reductase, Polyol pathway.

\section{INTRODUCTION}

Diabetes mellitus is a multifactorial disease characterized by hyperglycemia, ${ }^{1}$ lipoprotein abnormalities, ${ }^{2}$ raised basal metabolic rate ${ }^{3}$ and defective reactive oxygen species scavenging enzymes. ${ }^{4}$ Factors leading to hyperglycemia include decreased insulin secretion, decreased glucose utilization and increased production of glucose. This metabolic dysregulation associated with Diabetes mellitus causes secondary pathophysiologic changes in multiple organ system that imposes a tremendous burden on the individual with diabetes. Diabetic complications arise due to glycosylation damage to structural and functional proteins and reflect chronic failure to maintain blood glucose homeostasis. Other complications such as diabetic nephropathy, retinopathy, neuropathy and cardiomyopathy also prevail as a result of hyperglycemia. ${ }^{4}$

Among all the complications associated with this disease, diabetic cataract may be the most common microvascular complication. The risk of developing diabetic cataract or other microvascular complications depends on both the duration and the severity of hyperglycemia. ${ }^{5}$ Aldol reductase (AR) activation is one of the most important mechanisms responsible for the development of diabetic cataract.

Studies suggest that compounds which inhibit AR could be effective in the treatment of diabetic complications. Synthetic aldose reductase inhibitors (ARIs) are associated with many deleterious side effects and have low penetrability to target tissue. ${ }^{6}$ Hence a number of studies are on to tap natural sources of ARIs which could be useful in the management of diabetic complications. In this study, we have investigated the potential of Wattakaka volubilis root extract
Submission Date: 11-07-2018; Revision Date: 29-09-2018; Accepted Date: 29-12-2018

DOI: 10.5530/ijper.53.2.34 Correspondence: Dr. Anita Murali, Professor and Head Department of Pharmacology, Faculty of Pharmacy, M. S. Ramaiah University of Applied Sciences, MSRIT Post, MSR Nagar, Bangalore- 560054, Karnataka, INDIA. Phone: +91-9845105865 E-mail: anita.murali4@gmail. com

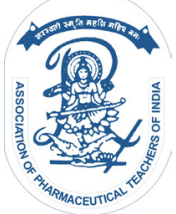

www.ijper.org 
for its aldose reductase inhibition potential and prevention of diabetic cataract in animals.

Wattakaka volubilis commonly known as green wax flower and cotton milk plant is a tall, woody climber with densely lenticellate and pustular branches. ${ }^{7}$ It is widely used in Ayurveda as one of the alternative sources of the drug Murva. The accepted botanical source of Murva is Marsdenia tenacissima (Roxb.) Moon. ${ }^{8}$ Murva is useful as analgesic, anthelmintic, antimutagenic, anticancer and antibacterial. ${ }^{9} W$. volubilis is traditionally used for various disorders. Plant juice is used as sternutatory, roots and tender stalks are used as emetic, purgative and expectorant. ${ }^{8}$ Leaves are used to relieve rheumatic pain, cough, fever and cold. ${ }^{10}$ Roots are used for lithiasis. ${ }^{11}$ The roots and leaves are used for skin diseases, diabetes, cough, jaundice, poison bites and for blood disorders. ${ }^{12}$ Leaf in paste form along with pepper is taken for dyspepsia, boils and abscesses. ${ }^{12,13}$ Leaf juice is reported to cure sprain; ${ }^{14}$ the plant useful for scorpion and snake bites. ${ }^{15}$ Paste of bark is taken with milk for urinary problems and leaf powder in milk is taken for diabetes. ${ }^{16}$

Many phytoconstituents have been isolated from $W$. volubilis such as steroids, triterpenoids, phenolic compounds and flavonoids from root; ${ }^{17} \beta$-sitosterol; aglycone drevogenin $A ; 9,12$ - octadecadienoic acid; quinic acid; 1, 2 - benzenedicarboxylic acid diisooctyl ester; 5, 7 - dihydroxy - 6,8 - dimethoxyflavone; N-[4-bromon-butyl]-2-piperidinone and digitoxose also from the root $;{ }^{17} \beta$-sistosterol, pregnane glycosides and kaempferol from bark. ${ }^{18}$ HPTLC evaluation of methanol extract of leaf of $W$. volubilis revealed the presence of oleonolic acid and urolic acid. ${ }^{19}$ Polyoxypregnane glycosides, volubiloside $\mathrm{A}, \mathrm{B}$ and $\mathrm{C}$ were isolated from the flowers; ${ }^{20}$ a triterpenoid ether, multiflor-7-en-12, 13-ether and a new multiflor-7-en-12 $\alpha$-ol was identified in $W$. volubilis. ${ }^{21}$ Glycosides dregeosides H, Dp1, Da1, Gp1, Ga1 and two biosides were isolated from the hydrolysate of glycosides from roots ${ }^{18}$ and seven glycosides dregeosides Ap1, Ao1, Aa1, A11, C11, Kp1 and Kal, Drevogenin $\mathrm{D}$ were isolated from the seeds and characterized as $3 \beta$, $11 \beta, 12 \beta, 14 \beta, 20 \xi$-pentahydroxypregn-5-ene. ${ }^{22}$

Various pharmacological studies have also been reported on $W$. volubilis such as antiurolithiatic ${ }^{11}$ and antipyretic activities $^{23}$ in root; anti-diabetic, anti-hyperlipidemic and antioxidant properties in leaf; ${ }^{24}$ wound healing ${ }^{25}$ and antibacterial property in root, stem and leaf. ${ }^{26}$

Hypoglycaemic activity in Murva $^{27}$ and antidiabetic activity of $W$. volubilis leaf ${ }^{24}$ have been reported. On the basis of these reports, the present work has been undertaken to determine the efficacy of $W$. volubilis root extract to prevent cataract formation in diabetic rats.

\section{MATERIALS AND METHODS}

\section{Collection of plant material and preparation of ethanol extract}

The plant material was collected from Kalakkad forests, Tirunelveli district, Tamil Nadu in flowering condition during March 2009. Identification, authentication and preparation of Herbarium specimen were done following standard protocols. ${ }^{28-31}$ Herbarium specimen (031) was deposited in the herbarium at the Department of Pharmacognosy, Faculty of Pharmacy, M. S. Ramaiah University of Applied Sciences. Bangalore.

Extraction with $95 \% \mathrm{v} / \mathrm{v}$ ethanol was carried out by Soxhlation method. The concentrated and dried extract (yield $5.67 \% \mathrm{w} / \mathrm{w}$ ) was suspended in $2 \% \mathrm{w} / \mathrm{v}$ acacia and used for the pharmacological studies.

\section{Phytochemical analysis}

Preliminary phytochemical screening ${ }^{32}$ was performed for the detection of different constituents present in the extract. Chromatographic studies were carried out. ${ }^{33,34}$ HPTLC studies ${ }^{35}$ were carried out using Camag HPTLC system equipped with Linomat $\mathrm{V}$ applicator, TLC scanner 3, Reprostar 3 with 12bit CCD camera for photo documentation, controlled by Win CATS- 4 software were used. All the solvents used were of HPTLC grade obtained from MERCK. Chloroform: methanol (8:2) was used as the mobile phase.

\section{Animals}

Albino Wistar rats of either sex bred and reared in the animal facility of our institution were used in the study. CPCSEA (Committee for the Purpose of Control on Experiments in Animals) guidelines were followed for the maintenance of experimental animals. Prior approval was obtained from the Institutional Animal Ethics Committee of the institution (IAEC certificate no. MSRCP/ M-41/ 2014).

\section{Acute toxicity studies ${ }^{36}$}

A limit test was performed as per test guide line 423 of OECD, using a dose of $2000 \mathrm{mg} / \mathrm{kg}$. After dosing, animals were observed closely for $24 \mathrm{~h}$ for any kind of toxic symptoms. They were under close monitoring for the following $48 \mathrm{~h}$ and subsequently up to $14 \mathrm{~d}$.

\section{Induction of diabetes mellitus ${ }^{37}$}

Diabetes was induced by single intraperitoneal injection of streptozotocin (STZ) in $0.1 \mathrm{~mol} / \mathrm{L}$ chilled citrate buffer, $\mathrm{pH} 4.5$, at the dose of $45 \mathrm{mg} / \mathrm{kg}$. After injection, 
animals were allowed to drink 5\% glucose solution overnight. ${ }^{38}$ The development of hyperglycemia in rats was confirmed by fasting serum glucose estimation $72 \mathrm{~h}$ post STZ injection, wherein the animals were fasted over night before blood withdrawal by puncturing retro orbital plexus. The rats with fasting serum glucose level $\geq 180 \mathrm{mg} / \mathrm{dL}$ were considered diabetic and were included in the study.

The diabetic rats were divided into 4 groups of 6 animals in each group as follows: Group II (Positive control) consisted the vehicle treated (Acacia 2\% w/v p.o) diabetic rats; Group III (Standard) included Glimepiride treated $(0.5 \mathrm{mg} / \mathrm{kg}$, b.w, p.o) diabetic rats; Group IV and Group V respectively consisted of the alcohol extract 100 and $200 \mathrm{mg} / \mathrm{kg}$ treated diabetic rats. Non diabetic rats were assigned as the normal control group (Group I).

Treatments were continued once daily for $21 \mathrm{~d}$. On the $22^{\text {nd }}$ day, fasting blood glucose was measured in all the animals. ${ }^{39}$ Treatment was continued from the $22^{\text {nd }}$ day onwards for further $15 \mathrm{~d}$ to evaluate the effects of the extract on diabetes induced cataract. At the end of the treatment, animals were sacrificed with excess of ether anesthesia and the lens was isolated by posterior approach. Lens homogenate was prepared in chilled phosphate buffer $\mathrm{pH}$ (7.4) for the estimation of $\mathrm{AR},{ }^{40}$ MDA, ${ }^{41,42} \mathrm{GSH},{ }^{43,44}$ SOD,${ }^{43,45}$ catalase, ${ }^{43,46}$ proteins, ${ }^{47,48}$ sodium and potassium ${ }^{49}$ calcium, ${ }^{50}$ Lactate Dehydrogenase $(\mathrm{LDH}),{ }^{51}$ Sorbitol Dehydrogenase ${ }^{52}$ and sorbitol..$^{53}$

\section{RESULTS}

Preliminary phytochemical analysis indicated the presence of glycosides and saponins in the alcohol extract. HPTLC fingerprint of the alcohol extract of $W$. volubilis root was obtained at wavelengths 254,366 and $425 \mathrm{~nm}$. Figure 1 represents the HPTLC fingerprint of the alcohol extract at $254 \mathrm{~nm}$.

The dose of $2000 \mathrm{mg} / \mathrm{kg}$ was found to be safe in female Wistar rats. Streptozotocin $45 \mathrm{mg} / \mathrm{kg}$ produced significant $(p<0.001)$ increase in blood glucose levels compared to the normal control animals. Diabetic rats treated with 100 and $200 \mathrm{mg} / \mathrm{kg}$ of the alcohol extract showed significant lowering of serum glucose levels. Results were statistically significant $(p<0.001)$ (Figure 2). Aldose reductase and MDA levels were found to be significantly decreased $(p<0.001)$ in the animals treated with the extract when compared with the positive control. GSH levels in lens of positive control animals were significantly $(p<0.001)$ lower than in normal rats. An elevation $(p<0.001)$ in the GSH levels were observed in the standard and extract treated groups.
The positive control animals showed a significant $(p<0.001)$ decrease in the SOD and catalase activity in the lens homogenate. The extract treated and the glimepiride treated groups showed significant increase $(p<0.001)$ in the level of these antioxidant enzymes.

SDH activity in the lens of STZ diabetic rats was significantly $(p<0.001)$ higher than the SDH activity in normal rats. A decrease in the SDH activity in the lens homogenate of extract and glimepiride treated groups in comparison with the positive control was observed.

LDH activity in the lens of STZ diabetic rats was $110.04 \pm 3.03 \mathrm{IU} / \mathrm{L}$ of tissue which was significantly $(p<0.001)$ higher than the LDH activity in normal rats $(56.16 \pm 2.92 \mathrm{IU} / \mathrm{L})$. $\mathrm{LDH}$ activity in the lens of STZ diabetic rats administered with alcohol extract at a dose of 100 and $200 \mathrm{mg} / \mathrm{kg}$ and glimepiride $(0.5 \mathrm{mg} / \mathrm{kg})$ was found to be significantly lower $(p<0.001)$ than that of diabetic control. There was a significant increase in the levels of sodium, potassium, calcium, total protein,

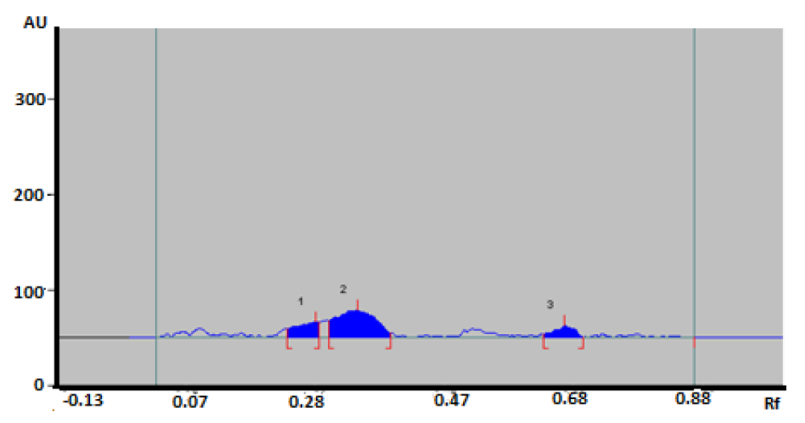

Figure 1: HPTLC fingerprint of alcohol extract of $W$. volubilis root at $254 \mathrm{~nm}$.

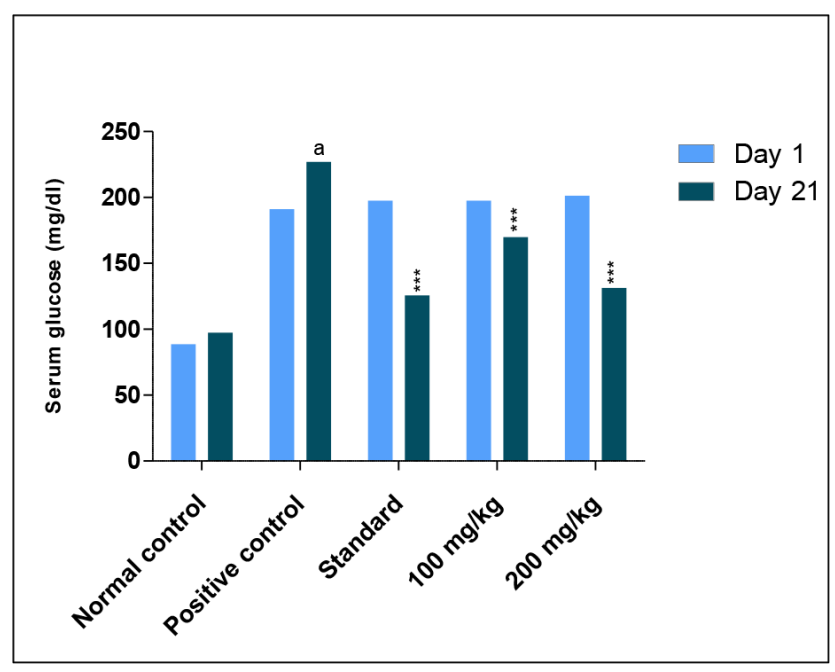

Figure 2: Effect of alcohol extract of $W$. volubilis root on serum glucose levels.

Values are expressed as Mean $\pm S E M ; n=6$. One-way ANOVA: $p$ value found to be 0.0001; Tukey-Kramer multiple comparisons test: ${ }^{a} p<0.001$ in comparison with Normal control; "* $p<0.001$ in comparison with the Positive control. 


\begin{tabular}{|c|c|c|c|c|c|}
\hline Parameters & Normal control & Positive control & $\begin{array}{c}\text { Standard } \\
\text { (Glimepiride) }\end{array}$ & $\begin{array}{c}\text { Alcohol extract } \\
(100 \mathrm{mg} / \mathrm{kg})\end{array}$ & $\begin{array}{c}\text { Alcohol extract } \\
(200 \mathrm{mg} / \mathrm{kg})\end{array}$ \\
\hline AR activity (nmol/100mg) & $0.95 \pm 0.03$ & $1.96 \pm 0.02^{\mathrm{a}}$ & $1.43 \pm 0.04^{* * *}$ & $1.00 \pm 0.03^{* * *}$ & $0.8 \pm 0.04^{* * *}$ \\
\hline MDA (nmol/100mg) & $0.36 \pm 0.02$ & $1.39 \pm 0.15^{a}$ & $0.74 \pm 0.04^{* * *}$ & $0.61 \pm 0.02^{* * *}$ & $0.60 \pm 0.02^{* * *}$ \\
\hline $\mathrm{GSH}(\mathrm{nmol} / 100 \mathrm{mg})$ & $51.22 \pm 0.32$ & $30.06 \pm 1.50^{a}$ & $43.34 \pm 0.28^{* * *}$ & $44.29 \pm 0.36^{* * *}$ & $46.00 \pm 0.25^{* * *}$ \\
\hline SOD activity (U/mg of tissue) & $3.31 \pm 0.04$ & $0.81 \pm 0.05^{a}$ & $2.64 \pm 0.04^{* * *}$ & $2.82 \pm 0.03^{* * *}$ & $2.90 \pm 0.04$ \\
\hline Catalase (U/mg of tissue) & $0.79 \pm 0.02$ & $0.17 \pm 0.01^{a}$ & $0.61 \pm 0.01^{* * *}$ & $0.67 \pm 0.01^{* * *}$ & $0.70 \pm 0.02^{* * *}$ \\
\hline Sodium (\%) & $0.15 \pm 0.01$ & $0.22 \pm 0.12^{a}$ & $0.08 \pm 0.01^{* * *}$ & $0.08 \pm 0.01^{* * *}$ & $0.07 \pm 0.01^{* * *}$ \\
\hline Potassium (\%) & $0.023 \pm 0.003$ & $0.098 \pm 0.004^{a}$ & $0.058 \pm 0.003^{* * *}$ & $0.061 \pm 0.003^{* * *}$ & $0.056 \pm 0.003^{* * *}$ \\
\hline Calcium (mg/dl) & $6.10 \pm 0.20$ & $11.41 \pm 0.40^{a}$ & $7.40 \pm 0.12^{* * *}$ & $7.76 \pm 0.11^{* * *}$ & $7.34 \pm 0.13^{* * *}$ \\
\hline $\mathrm{SDH}$ (U/mg of solid) & $0.37 \pm 0.002$ & $0.055 \pm 0.001^{a}$ & $0.055 \pm 0.003$ & $0.040 \pm 0.002^{* * *}$ & $0.031 \pm 0.001^{* * *}$ \\
\hline Sorbitol $(\mu \mathrm{g})$ & $0.71 \pm 0.09$ & $3.9 \pm 0.08^{a}$ & $2.0 \pm 0.08^{* * *}$ & $1.21 \pm 0.08^{* * *}$ & $1.05 \pm 0.08^{* * * *}$ \\
\hline LDH (IU/L) & $56.16 \pm 2.92$ & $110.04 \pm 3.03^{\mathrm{a}}$ & $98.50 \pm 3.00^{*}$ & $70.60 \pm 2.13^{* * *}$ & $66.91 \pm 2.50^{* * *}$ \\
\hline Protein (mg/dl) & $7.92 \pm 0.21$ & $2.63 \pm 0.07^{a}$ & $6.18 \pm 0.12^{* * *}$ & $10.63 \pm 0.17^{* * *}$ & $11.38 \pm 0.14^{* * *}$ \\
\hline
\end{tabular}

Values are expressed as Mean $\pm \mathrm{SEM} ; \mathrm{n}=6$. One-way ANOVA: $\mathrm{p}$ value found to be $0.0001 ;$ Tukey-Kramer multiple comparisons test: ${ }^{\mathrm{a}} \mathrm{p}<0.001$ in comparison with normal control; ${ }^{*} p<0.05$ in comparison with the positive control, ${ }^{\prime} * * * p<0.001$ in comparison with the positive control.

sorbitol in the lens homogenate of positive control $(p<0.001)$. Treatment of diabetic rats with the alcohol extract (100 and $200 \mathrm{mg} / \mathrm{kg}$ ) and glimepiride showed significant improvement in these abnormalities (Table 1).

\section{DISCUSSION}

The study was conducted to investigate the role of $W$. volubilis root in the prevention of diabetic cataract. A single intraperitoneal injection of STZ at a dose of $45 \mathrm{mg} / \mathrm{kg}$ produced significant hyperglycemia without any mortality. The major clinical signs of DM like polyphagia, polydypsia, polyuria and body weight reduction were observed in all the animals. The extract was found to be safe with $2000 \mathrm{mg} / \mathrm{kg}$ as shown by the acute toxicity studies. Based on this result, 100 and $200 \mathrm{mg} / \mathrm{kg}$ of the extract were selected for further pharmacological studies. Diabetic patients are predisposed to many problems associated with their disease. Among the entire complications, diabetic cataract, a major microvascular disease is the most common chronic complication of diabetes. ${ }^{54}$ Cataract, characterized by cloudiness or opacification of the eye lens, is the leading cause of blindness all over the world ${ }^{55}$ Cataractogenesis is one of the earliest secondary complications of DM particularly in rodents. Although the pathogenesis of development of diabetic cataract is unknown, a number of pathways arising as a result of hyperglycemia may be accounted for the development of cataract. Various mechanisms have been proposed to explain the pathophysiology of diabetic complications. These mainly include oxidative stress, increased polyol pathway or osmotic stress, increased formation of advanced glycation end products, activation of protein kinase $\mathrm{C}$ and increased hexosamine pathway flux. ${ }^{56}$ Among all these pathways, polyol pathway is very widely studied.

Aldose reductase is the main enzyme involved in polyol pathway pathway. It is the first and rate limiting enzyme of this pathway. ${ }^{57}$ Under normoglycemic conditions, AR has a minor role in glucose metabolism but its activity is significantly enhanced during diabetes. ${ }^{58,59}$ In hyperglycaemic condition, AR catalyses conversion of excess glucose to sorbitol in insulin independent tissues like lens. AR catalysed formation of excess polyols are considered as one of the mechanisms leading to diabetic cataract. ${ }^{60}$ Hence compounds that inhibit AR activity could be effective in the treatment of diabetic cataract. In the present study, STZ diabetic rats exhibited higher aldose reductase activity and which was normalised by both doses of $W$. volubilis root extract. The normalisation of aldose reductase activity can be well correlated with the improved biochemical status and prevention of cataract. Similarly, inhibition of SDH and $\mathrm{LDH}$ activities was also observed which further indicated the possible protective effect of the extract against cataract formation. Studies have indicated that intracellular accumulation of polyol leads to collapse and liquefaction of lens fibres, leading to opacity of lens. In this study, treatment with the extract decreased the sorbitol concentration in the lens which may be accounted for the delay in development of cataract. ${ }^{61}$

A decrease in GSH, increase in lipid peroxidation and altered activities of antioxidant enzymes were observed in various types of cataract, including diabetic cataract. ${ }^{49}$ All these above mentioned changes were also seen in the present study and was normalised by $W$. volubilis extract. 
Further, the accumulation of carbonyl groups in proteins is attributed to oxidative damage and is thought to contribute to general protein dysfunction as seen in diabetic control. ${ }^{49}$ Treatment groups showed a substantial increase in the total protein content of lens which indicates that the extract prevented the decrease in total protein content. All of these indicate that $W$. volubilis extract has anti cataract potential in Diabetes mellitus. Preliminary phytochemical screening revealed the presence of glycosides and saponins. Whether these phytoconstituents have contributed to observed effects, needs to be investigated further.

\section{CONCLUSION}

This study suggests that alcohol extract of $W$. volubilis root is effective against diabetes and diabetic cataract. However, further studies are needed to elucidate the mechanism(s) of action and to know the active principle/s involved in producing these effects.

\section{ACKNOWLEDGEMENT}

We acknowledge the Dean Faculty of Pharmacy and Management of M.S. Ramaiah University of Applied Sciences for supporting this research work.

\section{CONFLICT OF INTEREST}

The authors declare no conflicts of interests

\section{ABBREVIATIONS}

AR: Aldose Reductase; ARIs: Aldose Reductase Inhibitors; b.w: Body weight; CPCSEA: Committee for the Purpose of Control on Experiments in Animals; d: Day; dL: Deciliter; DM: Diabetes Mellitus; GSH: Glutathione; h: Hour; HPTLC: High Performance Thin Layer Chromatography; IAEC: Institutional Animal Ethics Committee; IU: International Units; kg: Kilogram; L: Litre; LDH: Lactate Dehydrogenase; MDA: Malondialdehyde; mg: Milligram; nm: Nanometer; OECD: Organisation for Economic Co-operation and Development; p.o: Per oral; SDH: Sorbitol Dehydrogenase; SOD: Superoxide Dismutase; STZ: Streptozotocin; $\boldsymbol{W}$. volubilis: Wattakaka volubilis.

\section{REFERENCES}

1. Ugochukwu NH, Banady NE, Cobourne M, Gasset SR. The effect of Gangronema latifoloum extracts on serum lipid profile and oxidative stress in hepatocytes of diabetic rats. J Biosci. 2003;28(1):1-5.

2. Scoppola A, Montecchi FR, Mezinger G, Lala A. Urinary Mevalonate Excretion rate in type 2 diabetes: role of metabolic control atherosclerosis. $J$ Biosci. 2001;156(2):357-61.
3. Owu DU, Antai AB, Udofia KH, Obembe AO, Obasi KO, Eteng MU. Vitamin C improve as basal metabolic rate and lipid profile in alloxan-induced diabetes mellitus in rats. J Biosci 2006;31(5):575-9.

4. Kesavulu MM, Giri R. Kameswara RB, Apparao C. Lipid peroxidation and antioxidant enzyme levels in type 2 diabetic with microvascular complications. Diab Metabol. 2000;26:387-92.

5. Keenan HA, Costacou T, Sun JK, Doria A, Cavellerano J, Aiello LP. Clinical factors associated with resistance to microvascular complications in diabetic patients of extreme disease duration: the 50 -year medalist study. Diab Care. 2007;30(8):1995-7.

6. Kinoshita JH, Nishimura $\mathrm{C}$. The involvement of aldose reductase in diabetic complications. Diab Metab Rev. 1988;4(4):323-7.

7. Gurudeva MR. Botanical and Vernacular Names of South Indian Plants. Bangalore: Divyachandra Prakashana. 2001.

8. Yoganarasimhan SN. Medicinal plants of India. Tamil Nadu. Bangalore: Cyber media. 2000;2.

9. Levekar GS. Data Base on Medicinal plants used in Ayurveda and Siddha. New Delhi: Central council for Reserach in Ayurveda and Siddha. 2007;8.

10. Muthu C, Ayyanar M, Raja N, Ignacimuthu S. Medicinal plants used by traditional healers in Kancheepuram District of Tamil Nadu. J Ethnobiomed. 2006;2(1):43-52.

11. Singh UK, Govil JN, Singh G. Recent progress in Medicinal plants in Ayurveda and Siddha. New Delhi: Central council for Research in Ayurveda and Siddha. 2007

12. Rajadurai M, Vidhya VG, Ramya M, Bhaskar A. Ethno-Medicinal plants used by the Traditional Healers of Pacchamalai Hills, Tamil Nadu, India. Ethnomed 2009;3(1):39-41.

13. Silija VP, Samitha VK, Mohanan KV. Ethanomedicinal plant knowledge of the Mullukuruma tribe of Wayananda district, Kerala. Indian J Trad Knowl. 2008;7:604-12.

14. Sanyasi RML, Verma YNR, Kumar V. Apply leaf juice by adding little lime on affected part to cure sprains once day till cured. Ethnobot Leaflets. 2008;12:217-26.

15. Jain SP, Verma DM. Medicinal plant in the folk-lore of north-east Haryana. Nat Acad Sci Lett. 1981;4(7):269-71.

16. Kumar P, Ayyanar M, Ignacimuthu S. Medicinal plants used by Malasar tribes of Coimbatore district, Tamil Nadu. Indian J Trad Knowl. 2007;6:579-82.

17. Joshi AB, Anvekar PK, Bhobe MP. Phytochemical investigation of the roots of Wattakaka volubilis. Der Pharma Chemica. 2013;5(3):112-5.

18. Rastogi RP, Mehrotra BN. Compendium of Indian Medicinal plants. Lucknow: CDRI. 1985.

19. Gopal V, Mandal V, Mandal SC. HPTLC evaluation of oleanolic acid and ursolic acid from the methanol extract of Wattakaka volubilis. J Acute Dis. 2014;3(1):59.

20. Shau NP, Panda N, Mandal NB, Banerjee S, Koike K, Nikaido T. Polyoxypregnane glycosides from the flowers of Dregea volubilis. Phytochemistry. 2002;61(4):383-8.

21. Niranjan RVL, Ravikanth V, Vijendra RA, Prabhakar RT, Venkateswarlu Y. An unusual novel triterpenoid ether, multiflor-7-en-12,13- ether and a new multiflor 7-en-12a-ol from Wattakaka volubilis. Tetrahed Lett. 2002;43(7):1307-11.

22. Rastogi RP, Mehrotra BN. Compendium of Indian Medicinal plants. Lucknow: CDRI and New Delhi: NISC 1980-1984. 1993;3

23. Madhavan V, Shukla AK, Murali A, Usha M, Yoganarasimha SN. Antipyretic activity studies of two botanical sources of the drug Murva. Asian J Trad Med. 2010;5(5):51-60.

24. Mohan VR, Maruthupandian A, Sampathraj R. Antidiabetic, antihyperlipidemic and antioxidant activity of Wattaka volubilis (L.F) Stapf leaves in alloxan induced diabetic rats. Int J Pharm Sci Res 2010;1(11):83-90.

25. Madhavan V, Goravankolla AK, Murali A, Yoganarasiman SN. Wound healing activity of the leaves of Wattakaka volubilis (L.f.) Stapf (Asclepiadaceae). Int J App Res Nat Prod 2012;5(3):23-9.

26. Shibu A, Dhanam S. Antibacterial efficacy of leaf, stem and root powders of Gmelina asiatica (L.) and Wattakaka volubilis (L. f) Stapf. Int J Curr Trad Res. 2013;2(1):100-4.

27. Nayak A. In vitro hypoglycaemic activity evaluation of Marsdenia tenacissima and Sphaeranthus indicus. Inventi Rapid- Ethnopharmacol 2014;(3). 
28. Gamble JS. The Flora of the Presidency of Madras. Dehra Dun: Bishen Singh Mahendra Pal Singh (repr.). 2005;2.

29. Saldanha CJ, Nicolson DH. Flora of Hassan District, Karnataka. New Delhi: Amerind Publishing Co. 1976;1.

30. Murthy KR, Yoganarasimhan SN. Flora of Coorg (Karnataka, India). Bangalore: Vimsat Publishers. 1990.

31. Jain SK, Rao RR. Field and herbarium methods. New Delhi: Today and Tomorrow Publishers. 1985.

32. Kokate CK. Practical Pharmacognosy. $4^{\text {th }}$ ed. New Delhi: Vallabh prakashan. 1999.

33. Harborne JB. Phytochemical methods. $3^{\text {rd }}$ ed. London: Chapman and Hall. 1998.

34. Stahl E. Thin layer chromatography. A laboratory hand book. $2^{\text {nd }}$ ed. Berlin: Springer. 2005.

35. Wagner H, Bladt S. Plant drug analysis. $2^{\text {nd }}$ ed. Berlin: Springer. 1996.

36. Organisation for economic co-operation and development (OECD) guidelines for testing of chemicals-423, Acute Oral Toxicity - Acute Toxic Class Method, $17^{\text {th }}$ December 2001. Retrived from http://www.iccvam.niehs.nih.gov/ Supp Docs/Fed Docs/ OECD/OECD _GL 423.

37. Vogel WH, Scholkens BA, Sandow J, Muller G, Vogel WF. Drug Discovery and Evaluation, Pharmacological Assays. $2^{\text {nd }}$ ed. Germany: Springer-Verlag Berlin Heidelberg. 2002.

38. Koneri RB, Samaddar S, Simi SM, Srinivas TR. Neuroprotective effect of a triterpenoid saponin isolated from Momordica cymbalaria Fenzl in diabetic peripheral neuropathy. Indian J Pharmacol. 2014;46(1):76-81.

39. Trinder P. Estimation of serum glucose. Annal Clin Bio Chem. 1969;6:24.

40. Hayman S, Kinoshita JH. Isolation and properties of lens aldose reductase. J Biol Chem 1965;240(2):877-82.

41. Chaterjee M, Sil PC. Hepatoprotective effect of aqueous extract of Phylanthus niruri on nimusulide induced oxidative stress in vivo. Indian J Biochem Biophy 2006;43:299-305.

42. Jose MM, Aledo JL, Cristina PG, Esterbandevalle A, Jose MS. Interrelationship between oxidative damage and antioxidant enzyme activtities: an easy and rapid experimental approach. Biochem Edu. 2000;28(2):93-5.

43. Sumanth M, Ahmed R. Antihepatotoxic and antioxidant activity of root of Taraxacum officinale in $\mathrm{CCL}_{4}$ intoxicated rats. Pharmacog Mag. 2008;4(16):188-94.

44. Paglia DE, Velentine WN. Studies on the quantitative and qualitative peroxidase. J Lab Clin Med. 1967;70(1):158-69.
45. Konoy. Generation of superoxide radical during oxidation of hydroxylamine and an assay for SOD. Arch Biochem Biophy. 1978;186(1):189-95.

46. Whiteside $\mathrm{C}$, Hassan HM. Introduction and inactivation of catalase and SOD of Escherichia coli by ozone. Arch Biochem Biophy. 1987;257:464-71.

47. Bablock W. A general registration procedure for method transformation. J Clin Biochem. 1988;26:783-90.

48. Brobeck JR. Physiological basis of medical practice. $9^{\text {th }}$ ed. Baltomore: Wilkins and Wilkins. 1973.

49. Vohra SB, Khan MS. Pharmacological Studies on Lepidium sativum. J Physiol Pharmacol. 1977;1(2):118-20.

50. Gitelman HJ. An improved automatic procedure for the determination of calcium in biologic specimens. Anal Biochem. 1967;18(3):521-31.

51. Schumann G, Bonora R, Ceriotti F, Ferard G. IFFC primary reference procedure for the measurement of catalytic activity concentrations of enzymes at $37^{\circ} \mathrm{C}$. Reference procedure for the measurement of catalytic concentration of lactate dehydrogenase. Clin Chem Lab Med. 2002;40:643-8.

52. Grelach U, Hiby W. Sorbitol dehydrogenase. In: Bergmeyer HU. Methods of enzymatic analysis. $2^{\text {nd }}$ ed. New York: Academic press. 1974.

53. West CD, Rapoport S. Colorimetric method for the estimation of dulcitol. Proc Soc Exp Biol 1949;70:142-45.

54. David MN. Long-Term Complications of Diabetes Mellitus. N Engl J Med. 1993;328(23):1676-85.

55. Suryanarayana P, Saraswat M, Petrash JM, Reddy GB. Emblica officinalis and its enriched tannoids delays streptozotocin induced diabetic cataract in rats. Mol Vis. 2007;13:1291-7.

56. Gutteridge JM. Lipid peroxidation and antioxidants as biomarkers of tissue damage. Clin Chem. 1995;41(12):1819-2.

57. Bhatnagar A, Srivastava SK. Aldose reductase: congenial and injurious profiles of an enigmatic enzyme. Biochem Med Metab Biol. 1992;48(2):91-121.

58. Gabbay KH. The sorbitol pathway and the complications of diabetes. N Engl J Med. 1973;288(16):831-6.

59. Ghahary A, Luo JM, Gong YW, Chakrabarti S, Sima AA, Murphy LJ. Increased renal aldose reductase activity, immunoreactivity and mRNA in streptozocin-induced diabetic rats. Diabetes. 1989;38(8):1067-71.

60. Varma SD, Schocket SS, Richards RD. Implications of aldose reductase in cataracts in human diabetes. Invest Ophthalmol Vis Sci. 1979;18(3):237-41.

61. Kinoshita JH. Mechanisms initiating cataract formation. Invest Ophthalmol 1974;13(10):13-24.
PICTORIAL ABSTRACT
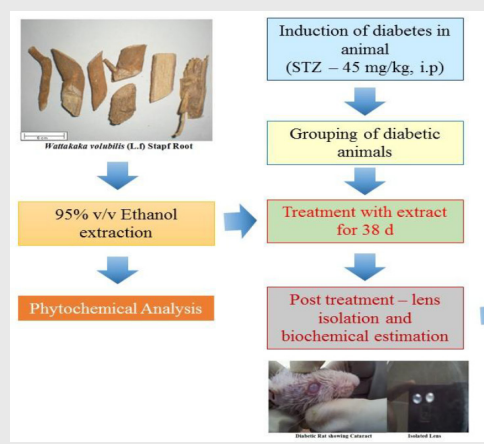

Confirmation of AR inhibition and decrease in cataract

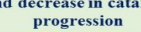

\section{SUMMARY}

- The present study investigated the anticataract potential of $W$. volubilis root extract against STZ induced diabetic rats. Ability of extract to inhibit aldose reductase and other markers in rat lens was determined. Treatment of diabetic animals with the alcohol extract of $W$. volubilis root showed significant aldose reductase inhibition and also decreased cataract progression.

\section{ABOUT AUTHORS}

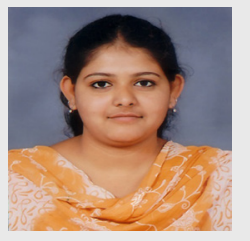

Hajira Banu $\mathbf{H}$ is an Assistant Professor in the Department of Pharmacology, Faculty of Pharmacy, Ramaiah University of Applied Sciences, Bengaluru. She has completed her B. Pharm and M. Pharm from M. S. Ramaiah College of Pharmacy, Bengaluru. She has 3 years of teaching experience and has published 4 articles in reputed journals. Currently, she is pursuing $\mathrm{PhD}$ at RUAS. Her areas of interest include metabolic disorders, Neuropharmacology and Nanotechnology. 


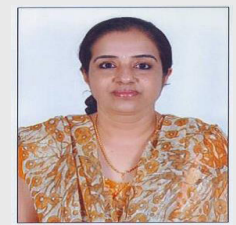

Dr. Anita Murali is Head of Department of Pharmacology, Faculty of Pharmacy, Ramaiah University of Applied Sciences, Bengaluru. She also holds the post of Associate Dean for UG programmes at Faculty of Pharmacy, Ramaiah University of Applied Sciences. She has over 26 years of teaching experience and 3 years of experience in Industry has published over 50 research articles in reputed journals. Her areas of research interest include and has Neuropharmacology, Diabetes and associated disorders and Cancer.

Cite this article: Haroon HB, Murali A. Alcohol Extract of Wattakaka volubilis (L.F) Stapf Root Inhibits Aldose Reductase to Prevent Diabetes Associated Cataract Formation in Rats. Indian J of Pharmaceutical Education and Research. 2019;53(2):261-7. 